\title{
A study of the history and use of integrated marketing communications within publications from 1991-2005
}

Shawn M. Benkahla

West Virginia University

Follow this and additional works at: https://researchrepository.wvu.edu/etd

\section{Recommended Citation}

Benkahla, Shawn M., "A study of the history and use of integrated marketing communications within publications from 1991--2005" (2006). Graduate Theses, Dissertations, and Problem Reports. 3225.

https://researchrepository.wvu.edu/etd/3225

This Thesis is protected by copyright and/or related rights. It has been brought to you by the The Research Repository @ WVU with permission from the rights-holder(s). You are free to use this Thesis in any way that is permitted by the copyright and related rights legislation that applies to your use. For other uses you must obtain permission from the rights-holder(s) directly, unless additional rights are indicated by a Creative Commons license in the record and/ or on the work itself. This Thesis has been accepted for inclusion in WVU Graduate Theses, Dissertations, and Problem Reports collection by an authorized administrator of The Research Repository @ WVU. For more information, please contact researchrepository@mail.wvu.edu. 


\title{
A STUDY OF THE HISTORY AND USE OF INTEGRATED MARKETING COMMUNICATIONS WITHIN PUBLICATIONS FROM 1991-2005
}

\section{Shawn M. Benkahla}

Thesis Submitted to the Perley Isaac Reed School of Journalism at West Virginia University in partial fulfillment of the requirements for the degree of

\author{
Master of Science in Journalism \\ R. Ivan Pinell, Ph.D. \\ George J. Esper, Ph.D. \\ Richard Bebout, M.S.J. \\ Marion C. Zwickel \\ Journalism Department \\ Morgantown, West Virginia \\ 2006
}

Keywords: Integrated Marketing Communications, Public Relations, Advertising, Persuasion, Marketing, Communications, Strategies, Theories 


\begin{abstract}
A Study of the History and Use of Integrated Marketing Communications within Publications Today

Shawn Benkahla

Integrated Marketing Communications is a relatively new concept which combines both aspects of public relations and advertising to create a more effective and cost efficient method to maintain public awareness and support. The concept of this study is to determine the effectiveness of integrated marketing communications within businesses today. To do the researcher used the means of content analysis in ten different publications through a fifteen year span. The ten publications consisted of four public relations, four advertising and two marketing printings.
\end{abstract}




\section{TABLE OF CONTENTS}

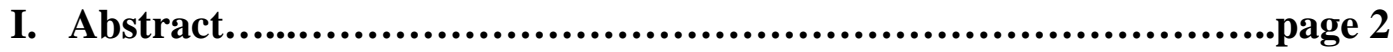

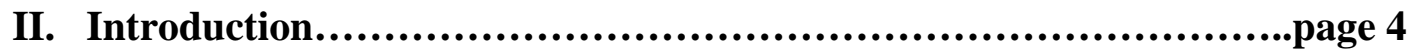

III. Research Question...................................................page 4

IV. Literature Review....................................................page 4

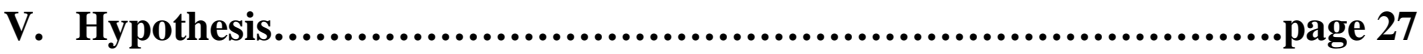

VI. Methods..................................................................page 28

VII. Results and Discussion...............................................page 30

VIII. Conclusion........................................................page 35

IX. Bibliography..........................................................page 38

\section{TABLE OF FIGURES}

I. Communication Model..............................................page 6

II. One-to-Many Communication Model.................................page 8

III. Marketing Mix Model..................................................page 8

IV. Integration of Fields Model...........................................page 21 


\section{INTRODUCTION}

The purpose of this study is to examine the history and current use of the integrated marketing communication tactic. This paper will also discuss the direct connection with strategies between integrated marketing communications and the fields of public relations and advertising. Lastly, this paper examines the ethical values of an integrated marketing communication program.

\section{RESEARCH QUESTION}

What is the history of integrated marketing communications? What strategies are used to create this program? Is integrated marketing communications receiving exposure and is it being used in today's society?

\section{LITERATURE REVIEW}

Integrated marketing communication is defined as a field that incorporates public relations, marketing, and advertising. In, 1991, Don Schultz, Dick Christian, Ted Spiegel, and Stan Tannenbaum were the founding fathers of IMC. They integrated the former advertising master's program with public relations and marketing courses at Northwestern University. The reason was to push organizations to direct their communication plans to work together with their customers, employees, and investors. ${ }^{1}$ The basis for IMC derives from the marketing communication strategy. There is no universal definition of integrated marketing communications and there are many interpretations. According to Delozier the definition is the most appropriate which states:

\footnotetext{
${ }^{1}$ www.medill.nwu.edu/alumni/ medillian/summer02/imc.pdf; pdf article about creation and use of IMC.
} 
The process of presenting an integrated set of stimuli to a market with the intent of evoking a desired set of responses within that market set....and...setting up channels to receive, interpret and act upon messages from the market for the purposes of modifying present company messages and identifying new communication opportunities. ${ }^{2}$

A primary function of the IMC program is the basis of marketing communications. According to James Hutton, marketing communications is defined broadly as "the sharing information or meaning that helps to identify, stimulate or satisfy customer wants or needs.”3 A more narrow and precise definition of marketing communications is:

"the strategic coordination of multiple communication voices with its aim to optimize the impact of a persuasive communication on both consumer and non-consumer audiences by coordinating such elements of the marketing mix as advertising, public relations, promotions, direct marketing, and package design.”4

The role of marketing communications is to create and maintain brand and

product loyalty by positively embedding this idea into the memory of the consumer. This is difficult because of the sheer amount of competition between similar products on the market. It is hard for a company or its product to stand out of the crowd. ${ }^{5}$ A way to correct this is to use the company itself as an umbrella to provide support from within its own stakeholder for the promotion. ${ }^{6}$

\footnotetext{
${ }^{2}$ Chris Fill, Marketing Communications: frameworks, theories, and applications, (London: Prentice Hall, 1995): 5.

${ }^{3}$ James G. Hutton, Marketing Communications: Integrated Theory, Strategy \& Tactics, (New Jersey: Pentagram Publishing, 2002): 2.

${ }^{4}$ Ed. Esther Thorson, Integrated Communications, (New Jersey: Lawrence Erlbaum Associates Publishers, 1996): 1.

${ }^{5}$ Ibid., 106.

${ }^{6}$ Fill, Marketing Communications, 15.
} 
There are several principles that contribute to the need to integrate marketing communications. Some key factors for this inevitability is the fact that major communication agencies have merged or combined with other agencies, the rising number of highly developed clients, the increasing cost to use conventional advertising methods, increasing worldwide competition, decreasing productivity of traditional media, the lowered cost of database access and use, and also the decline of a clear media message. ${ }^{7}$

The use of one main communications strategy for each major target audience is the basis for the theory of an IMC plan. This one tactic is then used as the foundation for performing each separate communications function like advertising and public relations throughout a variety different of communication channels. ${ }^{8}$

The main foundation of the integrated marketing communication program is loosely based primarily on the communication model (fig. 1.1 $)^{9}$ :

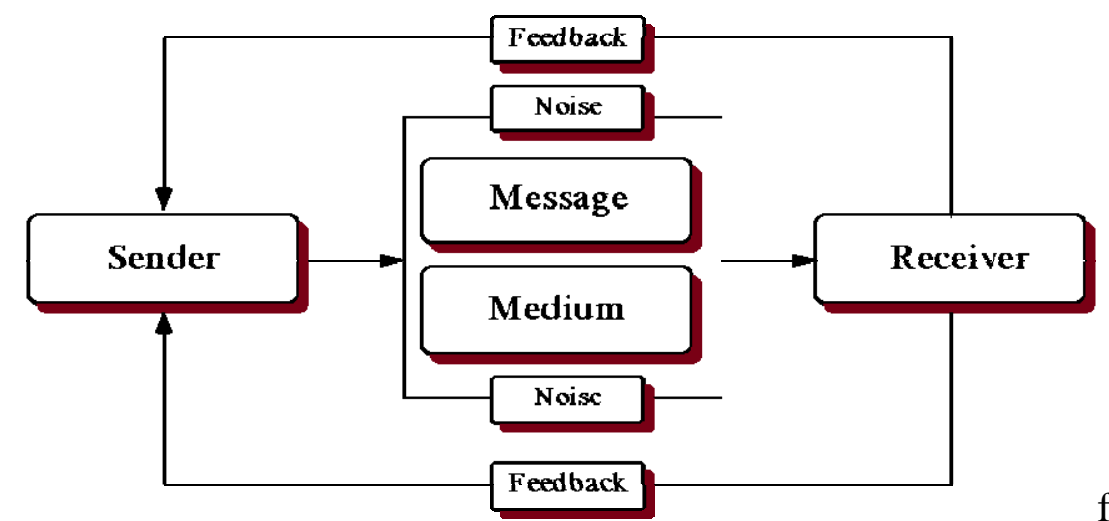

fig. $1.1^{10}$

\footnotetext{
${ }^{7}$ Thomas R. Duncan, Stephen E. Everett, Client Perceptions of Integrated Marketing Communications, Journal of Advertising Research, Vol. 33 Issue 3, May/June 1993, 30.

${ }^{8}$ Ibid.,31.

${ }^{9}$ Lewis Hersey, A Performance-Centered Approach to Marketing Education, Journal for Advancement for Marketing Education, Vol.1, 2001, 2.
} 
The sender represents the company or organization trying to convey a message to the consumer, which is represented as the receiver. The message is sent through different types of mediums, which interprets that message to the consumer. The receiver has the capabilities to provide a response back to the sender and communicate whether the message was understood or effective. An example of feedback is when an advertisement is shown on television that grabs the consumer's attention visually. A good marketing communications plan occurs when the consumer can correctly interpret the initial message as it was meant to be sent. ${ }^{11}$

Many firms communicate with their customers through various media outlets. The traditional media includes personal communication (word of mouth) and mass media (television and radio). The use of these media outlets is evident in the communication process of the one-to-many model (Fig. 1.2). ${ }^{12}$ The basis of this model is that a company or business, represented by the letter F, sends out their initial message to a media outlet, represented as the medium. The message is then distributed to a large number of consumers, represented by the letter C. Unlike the basic communication model (fig 1.1) this model does not have the capabilities to communicate between the business and the consumer. The communication flows one way. ${ }^{13}$

\footnotetext{
${ }^{10}$ Ibid., 2.

${ }^{11}$ Kenneth Clow, Integrated Advertising, Promotion \& Marketing Communication, (New Jersey: Prentice Hall, 2002): 7.

${ }^{12}$ Donna Hoffman, Thomas Novak, Marketing in Hypermedia Computer-Mediated Environments, Journal of Marketing. Vol. 60, Issue3, pg 52.

${ }^{13}$ Ibid.
} 


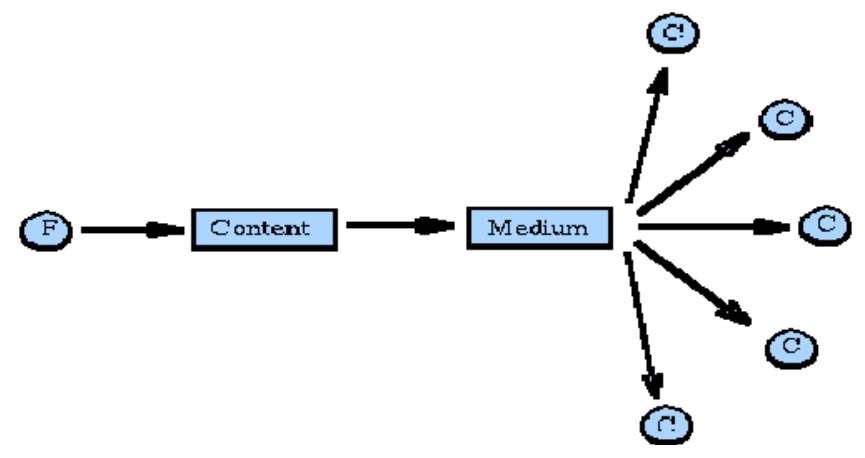

fig.1.2

The marketing mix (fig.1.3) ${ }^{14}$ is defined by Philip Kotler as "the mixture of controllable marketing variables that the firm uses to pursue the sought level of sales in the target market." ${ }^{\text {15 }}$ Marketing essentially is the ability to combine these principles of the marketing mix into a plan that will help push the economic process. The assumption was that with the use of the marketing mix there were numerous ways to satisfy what the consumer actually needs. ${ }^{16}$ Every aspect of the product, price, promotion, and place could be altered in a way to meet these needs.

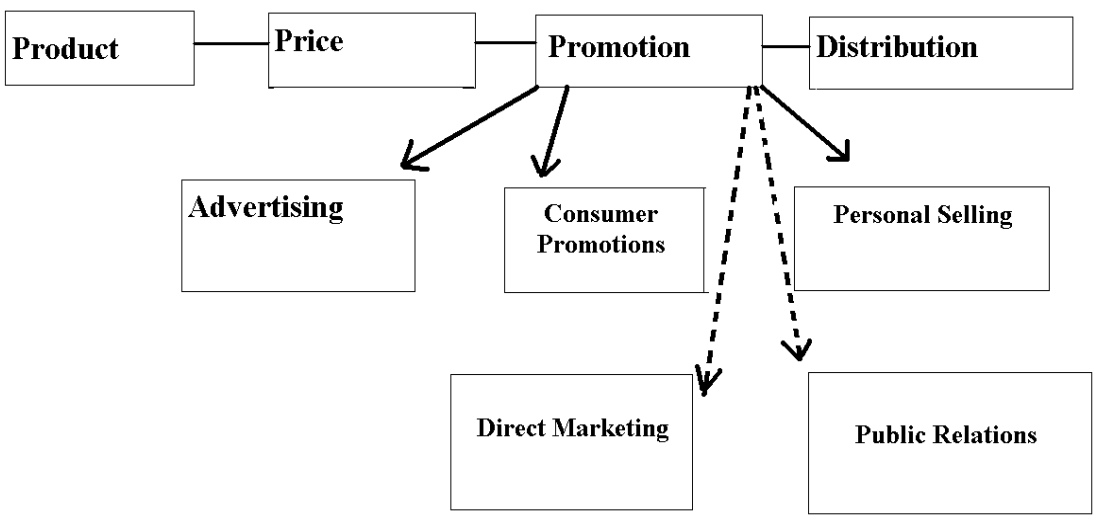

(fig.1.3) $)^{17}$

${ }^{14}$ Clow, Integrated Advertising, 9.

${ }^{15}$ Philp Kotler, Marketing Management: Analysis, Planning and Control, (New Jersey: Prentice Hall, 1984): 68.

${ }^{16}$ E. Jerome McCarthy, Basic Marketing, (Illinois: Richard D. Irwin, INC., 1981): 42.

${ }^{17}$ Clow, Integrated Advertising, 9. 
The tools of marketing communications are typically advertising, sales promotions, public relations, and personal selling. These aspects combined are typically known as the promotional mix. ${ }^{18}$ This mix is essential to have a successful IMC program. In theory if the plan fails to include aspects of the mix then the plan is seen as incomplete and the odds of that plan succeeding is drastically lowered. ${ }^{19}$

To truly understand the foundation of IMC one must first break down each aspect associated with this field. A key theory behind the creation and adaptation of the integrated marketing communication field is the general theory of persuasion. Persuasion is defined as, "human communication designed to influence the autonomous judgments and actions of others. ${ }^{20}$ Persuasion is essentially the use of messages to influence others.

The theory of persuasion is also known as the BVA theory, which receives its name from the key elements of the theory. ${ }^{21}$ These concepts are belief, value, and attitude. The basis of this is that all of these elements are connected. The attitude of the person being persuaded is the deciding factor if they feel positively or negatively towards something. A person's attitude can be created or changed simply by their personal beliefs and values. ${ }^{22}$

Persuasion is an important factor in communication and applies to the basic communication model (fig. 1.1). Persuasive communication can be viewed in three different principles. First, persuasion can be observed in of a negotiation process

\footnotetext{
${ }^{18}$ Fill, Marketing Communications,6.

${ }^{19}$ Clow, Integrated Advertising, 376.

${ }^{20}$ Herbert W. Simons, Persuasion in Society, (California, Sage Publications, Inc., 2001): 7.

${ }^{21}$ Ibid., 29.

${ }^{22}$ Ibid., 28-29.
} 
between people. Second, persuasion can be seen in the form of propaganda material typically associated with the government. The third and final element is when the sender or speaker is presenting their opinion to a large group of people with no chance for feedback from the crowd. ${ }^{23}$

There are many aspects which make up the concept of persuasion. These elements provide a basis and outline of how components of persuasion are made up. The principles include:

- Intent: We usually persuade intentionally, but we can also accidentally persuade. In fact every interpersonal interaction causes a change to both parties.

- Coercion: Coercion gains compliance, where behavior is changed, but without any internal commitment or change of inner mental systems (in fact these may be strengthened in the opposite direction).

- Context: A changed behavior may be constrained to limited context.

- Plurality: You can persuade one person or many people. You can even persuade just yourself.

- Presence: You can be physically with the other person (allowing maximum communication) or communicating via such as the telephone or written words.

- Media: Communication may be done through a range of media. ${ }^{24}$

These elements when put together can create a valuable tool that is used in the influencing of others. The ability to change someone's mind on a product or a subject is basis of what advertising and public relations is about.

Since persuasion is generally a broad theory there exist many different types of persuasion that pertain to the marketplace as well as everyday life. These different

\footnotetext{
${ }^{23}$ Fill, Marketing Communications, 23-24.

${ }^{24}$ changingminds.org/explanations/theories/persuasion.htm, this is a website dedicated on the study of the ability to change one another's minds.
} 
variables of persuasion can be seen from television all the way down to your family. The different variations of persuasion include:

- Reciprocation-this is the principle behind the Hare Krishna practice of handing out free flowers and the basis for the entire advertising-specialty business.

- Commitment and Consistency-a commitment to a decision or analysis.

- Social Proof-everyone goes along with the crowd.

- Likeability-physical attractiveness and likeability increase a person's influence.

- Authority-the ability to impart an unspoken message of influence based on authority.

- Scarcity-the less things there are the more valuable they are. ${ }^{25}$

In theory scholars feel that emotion can change the effectiveness of a persuasion

method. One major persuasion technique is that it influences emotion in the use of public service announcements. In a study performed by James Dillard and Eugenia Peck 140 undergraduate college students viewed eight PSA which induced some form of emotion into the students. ${ }^{26}$ The topics of the public service announcement included Lutheran ministries, anti-drugs, exercise, charities, infant safety, safe sex, community service, and drunk-driving campaigns. ${ }^{27}$ The reason for the experiment was to see if emotion can be used to persuade an individual. Some participants were told to use their emotions to evaluate the effectiveness of the PSA. The rest were told to swallow their emotions and not let it influence their decision on the effectiveness of the ad. ${ }^{28}$ After each student had rated the PSA's Dillard and Peck found that to observe the ads with no emotion aspects had no real difference than those that watched the advertisements emotionally in

\footnotetext{
${ }^{25}$ John Mariotti, Understanding Influence and Persuasion, Industry Week, Vol. 248, 1999, 126.

${ }^{26}$ James P. Dillard, Eugenia Peck, Affect and Persuasion: Emotional Responses to Public Service Announcements, Communication Research, Vol. 27 No. 4 August 2000. 461.

${ }^{27}$ Ibid., 490-491.

${ }^{28}$ Ibid., 461.
} 
determining how the message was processed. However, when it came to the impact of emotion on how persuasive the message was, they found a definite impact. ${ }^{29}$ This is an important finding because it shows that if an ad can induce a positive emotional response then the ad will have more of an effect to the consumer.

Persuasion is typically one of the most traditional goals of any advertising field. The use of advertisements can display an influential message that one product is better than others even if the product isn't. The ability to change a consumer's attitude and persuading them to even consider using a new product is typically a difficult one. The use of persuasive advertising is used more in the consumer market due to the fact that the public's perception can be changed easily through the right form of advertisement. ${ }^{30}$

The role of advertising within the concept of integrated marketing communications is evident within the promotional mix. Advertising is defined as commercial communications through mass media, by an identified sponsor. ${ }^{31}$ Advertising is a market in decline when in comparison with integrated marketing communications. Evidence shows that professionals are opting to invest more in marketing communications tools, more specifically public relations, direct marketing, and sales promotions. Advertising, which used to get approximately $70 \%$ to $80 \%$ of marketing mix dollars, is now lucky to get $30 \%{ }^{32}$ Instead, clients are willing to spending more money on public relations and direct marketing, and as a result they are receiving

\footnotetext{
${ }^{29}$ Ibid., 490.

${ }^{30}$ Clow, Integrated Advertising, 239.

${ }^{31}$ Hutton, Marketing Communications, 149.

${ }^{32}$ Thorson, Integrated Communications, 35; Integrated Communications Proposes Blending PR with Advertising \& Direct Marketing: Opportunity for One Clear Voice for Users? Or Danger of Deemphasizing Field’s Highest Value?, PR Reporter, May 4 1992, 1-2.
} 
better results. ${ }^{33}$ However, there have been some recent declines in the typical dominance of traditional advertising in the marketing communication mix, it is still a major component of marketing communications. Planning an IMC program requires the person in charge of the company to speak about creative and media questions, which usually are discussed in traditional advertising. These basic aspects are simply being implemented to a broader range of options to create an effective plan. ${ }^{34}$

Advertising works by the influencing of the consumer psychologically. These influences are used to create a sense of emotional attachment to the product brand as well as a positive feeling about that brand. The main objective of all advertisements is to persuade positively one or more of these psychological elements in a way that favors the product or brand name being advertised. ${ }^{35}$ The psychological states include:

- Awareness-the consumer's ability to recognize and recall a brand name in a variety of contexts.

- Knowledge-the consumer's understanding of the brand and its ability to provide certain benefits.

- Associations-the consumer's perception of the factors that relate to the brand. Associations can be attributes, benefits, people, consumption situations and others.

- Feelings-the consumer's sentiments toward a brand.

- Purchase intentions-the consumer's intent to buy a brand. ${ }^{36}$

For an effective communication plan to work, the company's message should not go over the target audience's head and follow the correct form or model of how

\footnotetext{
${ }^{33}$ Ibid., 35.

${ }^{34}$ Larry Percy, Strategies for Implementing Integrated Marketing Communications, (Linconlwood, IL: NTC Business Books, 1997):8.

${ }^{35}$ Hutton, Marketing Communications, 151.

${ }^{36}$ Ibid., 150-151.
} 
traditional advertising actual works. ${ }^{37}$ Theoretically however, a single form of the correct way advertising should work does not exist. Numerous frameworks have come up which display a combined aspect of how advertising works. According to Hall and O’Malley there are four main advertising frameworks. These frameworks are:

- The sales framework: advertising is thought to have a short-term, direct impact on sales. Only on sales will the true effect of any advertising be felt.

- The persuasion framework: persuasion is affected by gradually moving buyers through a number of sequential steps. This hierarchy of effects models assumes that the buyer's decision making is rational and can be accurately predicted.

- The involvement framework: involvement-based advertisements work by drawing members of the target audience into the advertisement.

- The salience framework: salience models are based upon the premise that advertising works by standing out, by being radically different from all other advertisements in the same product class. ${ }^{38}$

Another effective model that helps in both determining the objectives for advertisements and identifying the best communication strategy is the hierarchy of effects model. The model suggests that a consumer follows these steps in order when they are being persuaded to purchase a product:

1. awareness

2. knowledge

3. liking

4. preference

5. conviction

6. the actual purchase $\mathrm{s}^{39}$

\footnotetext{
${ }^{37}$ Fill, Marketing Communications, 287.

${ }^{38}$ Ibid., 287-288; M. Hall, Using Advertising Framworks, Admap, March 1992, 17-21; D. O’Malley, Sales Without Salience?, Admap, September 1991, 36-39.

${ }^{39}$ Kenneth Clow, Integrated Advertising, 299-300.
} 
This model shares some qualities with other concepts about the change of attitudes. A primary theory is the concept of cognitive, affective, and conative elements of attitudes. ${ }^{40}$ The cognitive element is the consumer's mental comprehension of the product. The affective element is based on the consumer's attitude towards the product. Finally the conative principle is what the consumer will do physically or mentally concerning the product. This model flows in that particular order:

$$
\text { Cognitive }>\text { Affective }>\text { Conative. }^{41}
$$

Advertising has some advantages and disadvantages. The advantages are that it can be quickly implemented and have widespread coverage. The people who send the initial message have control of what goes into the content of the ad. If the ad is deemed ineffective or has a negative effect then the advertisers can easily terminate the ad and make the necessary adjustments to make it more effective. ${ }^{42}$ The disadvantages to advertising are that the plans cannot target individual customers making it harder to determine if the plan is actually working effectively. It is also difficult to change the message due to the fact that the message is dispersed quickly through the mediums. Finally, it is financially difficult to measure how cost effective the ad campaign was in the marketplace. ${ }^{43}$

With the use of advertising components and tactics IMC also uses elements from the public relation field. According to James Grunig and Todd Hunt, a majority of

\footnotetext{
${ }^{40}$ Ibid., 300.

${ }^{41}$ Ibid., 300.

42 Thomas L. Powers, Should you increase sales promotion or add salespeople?, Industrial Marketing Management, 1989, vol. 18, issue 4, 261.

${ }^{43}$ Ibid., 261.
} 
society views public relation as "being a pleasant fellow and glad-handling, simple publicity, lobbying, advertising, or propaganda”. ${ }^{44}$ However the practice of public relations is more diversified than what people think. The definition of public relations as quoted from the newsletter Public Relation News states:

Public relations is the management function which evaluates public attitudes, identifies the policies and procedures of an individual or an organization with the public interest, and plans and executes a program of action to earn public understanding and acceptance. ${ }^{45}$

Public relations can be traced as far back 1800 BC when Persian farmers were told how to handle the problem of field mice and how to harvest their crops through posted bulletins. A majority of the art and literature from the past were specifically created to create and maintain support for people in political or religious power. ${ }^{46}$

The theoretical frameworks for the principles of public relations are explained in the classical four public relations models. These four elements are the basis for the communication process of public relations and are the foundations for the practice of this field. They also demonstrate the balance of communication maintained by a public relations practitioner between a company and the public. ${ }^{47}$ The four models include press agentry/publicity, public information, two-way asymmetrical, and two-way symmetrical. These models are different in the function that they provide to the business that they work for. Even though public relations is used as way to communicate persuasively, not every

\footnotetext{
44 James Grunig, Todd Hunt, Managing Public Relations, (New York: Holt, Rinehart, and Winston, 1984):4.

${ }^{45}$ Ibid, 8; 127 East $80^{\text {th }}$ St. New York, NY 10021.

${ }^{46}$ Clarke L. Caywood, The Handbook of Strategic Public Relations \& Integrated Communications,(Boston, MA: McGraw Hill, 1997): 15.

${ }^{47}$ Grunig, Managing Public Relations, 23.
} 
model uses it for that purpose. ${ }^{48}$ Since these models are vital to the underlying foundation of public relations it is important to define each model more in-depth.

The press agentry/publicity model was developed between 1850-1900. This is for organizations or companies that equally use public relations with aspects of publicity and/or promotions. This principle's main focus is to achieve mass media coverage. The best example of this in today's market is sporting promotions and movie premieres. ${ }^{49}$ Phineas T. Barnum is widely seen as the one of the greatest and most famous press agents ever. He created false characters like the Cardiff Giant but still managed to develop such a high demand for them by simply claiming that they were truths. The local papers wrote editorials and news about these claims as being false and called Barnum a fraud, but as a result of this talk public attention was brought to these created figures. This ability to manipulate the media to help his business lives up to Barnum's famous quote, "there is no such thing as bad publicity”. ${ }^{50}$

Public information was introduced in the beginning of 1900 as the one-way distribution of objective information about an organization to a public. This is the most frequently practiced model today. An estimated 50 percent of PR practitioners use this method. ${ }^{51}$ This tactic is practiced within government agencies and nonprofit agencies. This model has frequently been linked with the concept of public relations as propaganda. Organizations usually keep very active press relations with the media offering constant news about the organization or agency. They also offer materials to be distributed to the

\footnotetext{
${ }^{48}$ Ibid., 21.

${ }^{49}$ Ibid., 22-25.

${ }^{50}$ Ibid, 28.

${ }^{51}$ Ibid., 26.
} 
public like fact sheets and other information pamphlets. ${ }^{52}$ Muckrakers were the main reason for the creation of this form of public relation. Muckrakers would try and uncover hidden and/or harmful information about a business or organization and distribute it to the public. ${ }^{53}$ However, with the creation of this practice information about an organization was readily available for the public to view.

The third model is the two-way asymmetric which was created in the 1920 s as a system that allows an organization to put out its information and to receive feedback from its publics about that information. However, the organization does not necessarily respond to that feedback in the way the public has requested. ${ }^{54}$ Under this model, an organization would not change a decision as a result of feedback, but might instead concentrate on putting across its preferred option to publics in a more favorable and effective way. ${ }^{55}$ The method was created by Edward Bernays, a practitioner for the Committee on Public Information, who is known for working with the Rockefellers in 1914 to rebuild their name after the coal miners strike in Colorado. ${ }^{56}$ Bernays took the original concept of propaganda and expanded on it to fit in a business field even though it was principally used in politics. Bernays is also one of the thinkers who developed the two-symmetric model. ${ }^{57}$ Bernays felt that the public could only be influenced into doing

\footnotetext{
${ }^{52}$ Ibid., 22-26.

${ }^{53}$ Ibid., 31.

${ }^{54}$ Ibid., 23.

${ }^{55}$ Ibid., 24-25.

${ }^{56}$ Ibid., 30-31.

${ }^{57}$ Ibid., 39.
} 
what was best for them. He felt that the management should be convinced that the individual's interest comes first before the public would ever accept the company. ${ }^{58}$

Finally, the two-way symmetric was produced in 1960 s and $70 \mathrm{~s}^{59}$ as a model that promotes free and equal communication between an organization and the publics. This may result in either the organization or its public being persuaded to change their position by keeping a free and open communication system. The public relations effort is found to be highly effective even if the organization or public doesn't change their opinions and feelings as long as they communicate well enough to understand where the other is coming from. ${ }^{60}$ Within this method there is no sender or receiver labels associated with either side since communication is occurring rapidly instead it is easier to designate them as person or group I and person or group II. ${ }^{61}$

Public relations are used in different ways when discussed in context with integrated communications. These roles are defined as the creation and support of a corporation's good will with the public and the stability needed for the support of a product by the public. $^{62}$ The first role is the conventional role of developing positive relations and interests between the company and its various key stakeholders (consumers, employees, and stockholders). Its primary task is to provide a series of signals (mental and visual) by which the stakeholders can recognize, understand, and place the company in such a way that the company builds a strong reputation with the public. The second

\footnotetext{
${ }^{58}$ Ibid., 40.

${ }^{59}$ Ibid., 25.

${ }^{60}$ Ibid., 23.

${ }^{61}$ Ibid., 24.

${ }^{62}$ Fill, Marketing Communications, 405.
} 
role is to create support for the marketing of the company's product. In theory this occurs with the integration of public relations with the other principles of the marketing mix. $^{63}$

Public relations and advertising complement each other within the principle of IMC. When a new product is created the company's launches a campaign to first bring attention to the media and as a result the consumers become aware of the existence of the product. A competitive advantage is built when these elements are planned correctly and if events are coordinated aspects of the promotional mix. ${ }^{64}$

With the use of public relations, advertising, and marketing communications there must be a balance of these principles if integrated marketing communications is to work properly. All principles of marketing communications should work in with the other aspects of public relations and advertising. ${ }^{65}$ The combination of all these fields working together is represented in figure 1.4. ${ }^{66}$ These fields are typically integrated however sometimes they are not. The reason for this occurring is simply based on the function of a lack of communication and cooperation. In theory a company or business should always want these elements of their organization to be integrated and working together. However in most instances the elements of marketing communications are designated as either being marketing or a communications tool. ${ }^{67}$

\footnotetext{
${ }^{63}$ Ibid., 406.

${ }^{64}$ Ibid., 406.

${ }^{65}$ Ed. Robert L. Heath, Handbook of Public Relations, (Thousand Oaks, CA: Sage Publishing, 2001):209.

${ }^{66}$ Ibid., 210.

${ }^{67}$ Ibid., 210.
} 


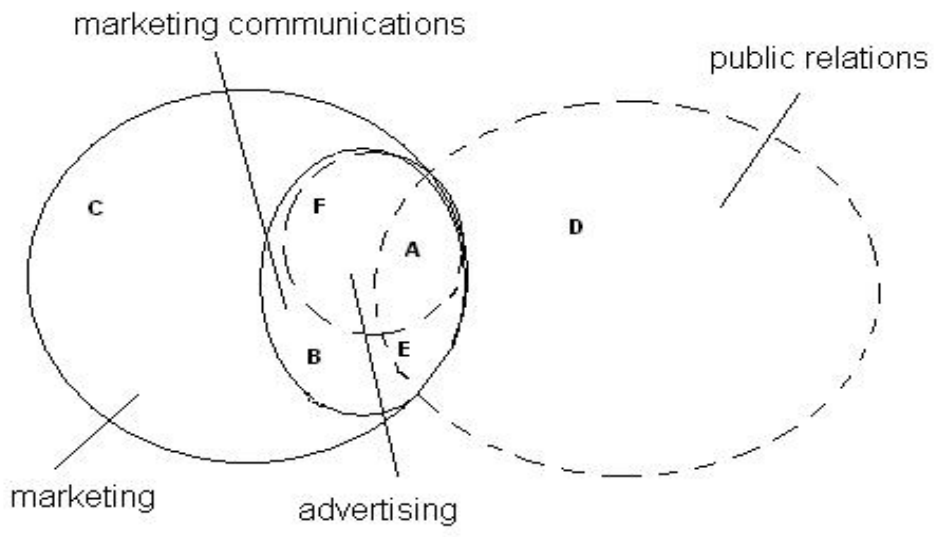

(fig 1.4) $)^{68}$

\begin{abstract}
$\mathbf{A}=$ corporate advertising $\mathbf{B}=$ sales force and marketing channel communications, direct marketing, promotion, trade shows, packaging.

$\mathbf{C}=$ distribution, logistics, pricing, location analysis, new product development $\mathbf{D}=$ investors relations, community relations, employee communication, media relations, public affairs, crisis communications, corporate identity, executive communications, charitable donations $\mathbf{E}=$ product publicity, part of media relations, part of crisis communication, collateral materials, part of corporate identity, sponsorships $\mathbf{F}=$ traditional mass media advertising $^{69}$
\end{abstract}

This integration affects all of a company's business-to-business relations, marketing communication channels, consumer directed communications, and communication within the company at a minimal cost to the business. ${ }^{70}$

There are some weaknesses when discussing the field of integrated marketing communications. This is a program that many professionals feel is a fad which is due to it not having a clear definition or meaning and a short lived influence on the market and

\footnotetext{
${ }^{68}$ Ibid., 210; James G. Hutton, Integrated Marketing Communication and the Evolution of Marketing Thought, Journal of Business Research, vol. 37, issue 3, 1996, 155-162.

${ }^{69}$ Ibid., 210.

${ }^{70}$ Clow, Integrated Advertising, Promotion, 9.
} 
other marketing fields. ${ }^{71}$ Another weakness is that there is no standard form of testing the effectiveness of an IMC plan.

Critics of the IMC program suggest that this just a more recent way for advertising companies to make more money and take away business from the communication fields. ${ }^{72}$ Advertising veterans feel that IMC is just a different name of similar practices such as the "whole egg”, “orchestration”, “new advertising”, and “seamless communication ${ }^{73}$,, which attempted to combine advertising and communication principles to make them more rational and reliable. All of these fields failed due to the unwillingness of major advertising companies to let go of their old methods of marketing which had worked for them in the past. ${ }^{74}$

Thomas Duncan and Stephen Everett investigated in a cross-sectional study of client organizations the views and organization of IMC programs. However, due to the lack of materials to properly support the creation of strong hypothesis the study was broken into six research questions:

1) How far are the responsibilities of marketing communications tools combined within or outside the company?

2) Do clients know what the term integrated marketing communications mean and does this affect them from an organizational and responsibility basis?

3) How valuable could an IMC program be to a company?

4) What are the important features of an IMC program?

5) What are the potential fall backs to using this program?

6) Is an agency's sales ability related to the use and views of IMC? ${ }^{75}$

\footnotetext{
${ }^{71}$ Hutton, Marketing Communications, 4.

${ }^{72}$ Heath, Handbook of Public Relations, 209.

${ }^{73}$ Duncan, Client Perceptions, 30.

${ }^{74}$ Heath, Handbook of Public Relations, 209.

${ }^{75}$ Duncan, Client Perceptions, 32.
} 
A group of 500 people were picked from a subscription list from the publication called Advertising Age. These people were identified as marketing or communication managers who specifically worked with clients. ${ }^{76}$ Some major results of this experiment were out of the 216 people who responded 59 percent were familiar with the term of integrated marketing communications with a 6.7 percent margin or error. ${ }^{77}$ This could be possible due to the fact that IMC could be talked about under a different name like "new advertising” or “orchestration”. ${ }^{78}$ Fifty-six percent of the responses felt that a successful IMC program is based on an outside agency and the client taking the initiative and 42 percent felt that the client should do it by themselves. ${ }^{79}$ Duncan and Everett used a Likert scale to rank the views of IMC ranging from one being strongly agree to five meaning strongly disagree. Some key findings were that the overall consensus is that IMC reduces the waste of media as well as gives a company a competitive edge in their field. They also found out that IMC does not really affect their hiring habits. A key finding was that a majority of the responses felt that IMC was beneficial to marketing and communications. ${ }^{80}$ With all of these findings there is still a lingering question that could not be answered, should a communications program be integrated? This is due to the

\footnotetext{
${ }^{76}$ Ibid., 32-33.

${ }^{77}$ Ibid., 35.

${ }^{78}$ Ibid., 38.

${ }^{79}$ Ibid., 35.

${ }^{80}$ Ibid., 35, 37.
} 
lack of critical data which proves how effective and efficient using IMC principles to complete the tasks of a marketing communication plan. ${ }^{81}$

A major downfall that some professionals see within IMC is the possibility for the "boomerang effect". ${ }^{82}$ This effect occurs because the main focus of importance is on the receiver's or consumer's response. If the integration process results in a clear understanding of the message by the consumer from the company, then there is a positive effect with the plan. However, if the consumer does not understand or does not like the message then there is negative effect. As a result the positive or negative feedback from the consumer is sent back to the agency where they discuss the effectiveness of the campaign. If there is a strong negative effect then the company will experience a boomerang effect where this effect will cause the company to pull the ad and make changes to create an ad that the consumer will have a positive response to. ${ }^{83}$ To prevent this from occurring the company's initial message and aspects of marketing communications should be integrated properly to create a more concise message.

The primary method to test the effectiveness of an IMC plan is based on the return of investment. ${ }^{84}$ The return on investment is determined by measuring how profitable a company was. The profitability is reached by a company's fiscal year income divided by stock equity and finally adding their debt. ${ }^{85}$ The higher the return on investment the more positive the IMC plan was. This method is seen as a short term

\footnotetext{
${ }^{81}$ Ibid., 38.

${ }^{82}$ Thorson, Integrated Communications, 54.

${ }^{83}$ Ibid., 54.

${ }^{84}$ Philip J. Kitchen, Lynne Eagle, IMC: Conclusions and Caveats, IMC Communique, Winter 2004, 1.

${ }^{85}$ http://www.investorwords.com/4316/ROI.html. definition of ROI.
} 
evaluation for an IMC plan. The testing of the effectiveness of an IMC plan is broken down into five different parts. The first is the short-term outcome which includes sales and the use of items like coupons. The next test is the long-term result with evaluates the creation of both brand awareness and loyalty. The ability for the consumer to be aware of a new product from this brand is the next method of evaluation. Being aware of the company and having a positive image of both the company and the brand are the last two methods of testing the effectiveness of an IMC plan. ${ }^{86}$ A shortcoming of an IMC plan is the inability of businesses to properly fund the required evaluation of the plan. Clients do not want to spend extra money on behavioral databases of their consumers because they feel that they have accumulated enough information in that short time. ${ }^{87}$

There are numerous strong qualities when arguing the use of an integrated marketing communication program. The first is that with the decline of traditional advertising campaigns, IMC must be implemented within advertising agency for them to survive. This is due to a waning advertising field that is viewed as a self-contained system in which agencies get paid in direct proportion to how much of their client's money they spent. Another reason for the decline is the business mentality concerning clients, which is the kill or be killed way of thinking. Agencies could lose their clients at any time to competition and they could take other companies clients as well. Companies routinely lower themselves to demoralizing pitches and competition reviews. ${ }^{88}$ With these instabilities ad agencies are taking steps to keep money coming into the advertising

\footnotetext{
${ }^{86}$ Clow, Integrated Advertising, 583.

${ }^{87}$ Kitchen, IMC: Conclusions and Caveats, 1.

${ }^{88}$ Hutton, Marketing Communications, 6.
} 
field. These agencies are making changes from the rebuilding of account groups to assisting clients in finding a more useful and beneficial marketing help outside of the traditional advertising realm. ${ }^{89}$ More clients are also willing to spend more money on public relations programs due how much money they could potentially save. The capabilities to reach a larger audience and the fact that better results were being obtained also led more clients to support public relations. ${ }^{90}$

Companies see IMC as a way to execute a quality element in their marketing communication program. IMC programs are more focused on the customer's wants and needs, integrated marketing communications promises "bigger bang for the buck ${ }^{91 \text { ” }}$ which means a higher quality with a lower cost. Integrated marketing communications offers the ability for customer input within the planning process. This gives an enhanced feel of what the consumer is looking for, compared to general databases typically used. An additional positive feature is the ability for companies to create interpersonal and cross-functional communications. This opened communication with the marketing branches and other communication divisions. The open communication lines prevented the message and its meaning from being lost or distorted when creating a plan.

As businesses change their wants and needs so must the marketing communication fields if they are to stay competitive. They must use different methods and strategies from all aspects of pubic relations and the marketing mix to create a more quality-based and contemporary communication program to help create and distribute the

\footnotetext{
${ }^{89}$ Percy, Strategies for Implementing, 6.

${ }^{90}$ Thorson, Integrated Communication, 35.

${ }^{91}$ Ibid., 52.
} 
message of a company to its target audience. IMC utilizes all aspects of these tools to create a more productive and cost efficient program ${ }^{92}$ by which many of today's advertisers and manufactured goods companies have implemented a form of this program with its branches. Though some people feel that this is another program fad ${ }^{93}$ many advertising companies feel that this is a field that is here to stay. ${ }^{94}$

\section{HYPOTHESIS}

H1: Journal publications will discuss integrated marketing communication evaluation strategies more than weekly trade publications.

H2: The trade publications will predominantly focus on how the company or school is using the campaign.

H3: Trade publications will predominantly focus on the qualitative aspects of an IMC campaign rather than the quantitative.

H4: Journal publications will predominantly discuss the quantitative aspect of the campaign.

H5: There will be more articles on the use and practice of IMC than there will be on the actual testing of an IMC campaign in both types of publications.

${ }^{92}$ Ibid., 52.

${ }^{93}$ Heath, Handbook of Public Relations, 209.

${ }^{94}$ Hutton, Marketing Communications, 6. 
H6: Integrated Marketing Communications will have been discussed more in the 2000's publications than in the 1990's publications.

\section{METHODS}

As a result of the information obtained through the literature review, a study will be conducted to further understand the impact of IMC within the fields of public relations and advertising. Through the literature review it has shown that there is no concise method to test the effectiveness of an IMC campaign. Typically, companies use techniques from the advertising, public relations, and marketing fields to determine the extent of the plan. This research will show how IMC has affected these three fields through the articles written about this new program.

The method used to show this understanding will entail the examination of publications. The process itself will be a content analysis of ten different publications. The first set will be of four advertising printings and the other set will be that of four public relations periodicals. Each set consists of either a trade publication which is printed weekly and the others are peer-reviewed journals. The printings titles include “Communication World,” "Public Relations Review,” “Journal of Public Relations Research,” and “Public Relations Quarterly” for the public relations field. For the advertising field the publications “Advertising Age,” “Journal of Advertising Research,” “Brand Week,” and “Journal of Advertising” are also going to be used. The marketing 
publications will consist of "The Journal of Marketing” and "Marketing News”. These publications are widely known throughout each field associated with its topic.

These publications were also from a specific time frame between 2001 and 2005. There will also be 5 years randomly selected between 1990 and 1999. The way that these years will be selected is by writing each year on a piece of paper and randomly pulling them out of a hat until the researcher has five different years choosen. The reason for setting a time frame for the sample size is that it provides more information by expanding the time frame from IMC's introduction to the current year. Another reason for expanding the time frame is the need for a more precise and accurate finding and outcome.

Through this experiment there should be an understanding of which publications discuss IMC and in what way, whether it is qualitative or quantitative. Also, through this study there should be knowledge as to the way companies test IMC and whether if an accurate testing process exists. This information will be helpful for later research on the creation of a qualitative method for testing integrated marketing communication plans.

\section{RESULTS AND DISCUSSION}

H1: Journal publications will discuss integrated marketing communication evaluation strategies more than weekly trade publications.

In the first hypothesis it stated that peer-reviewed journals will contain more evaluation methods for integrated marketing communications. Out of the 242 articles concerning IMC, 70 of them were from peer-reviewed journals. The other 172 articles were from trade publications. From those 70 articles from the peer-reviewed journals only 16 of them discussed methods of evaluation for integrated marketing 
communications. Trade publications had a total of 18 articles on evaluation methods. Even though trade publications had a higher number of articles concerning evaluation strategies, peer-reviewed journals had a better percentage of finding an article on this particular subject. A researcher could find an article on evaluation methods for integrated marketing communications $23 \%$ of the time in a peer-reviewed journal compared to just $10 \%$ for trade publications. Within the journal publication it discussed IMC as it relates to another study or topic. IMC is primarily used as a reference tool in these publications. However, in the trade publications they typically discuss how companies used an IMC campaign and how they tested how effective or non-effective it was.

In one article they discuss how tactics like ROI and measurement benchmarks are vital to quantitative analysis. ${ }^{95}$ ROI which stands for return on investment is a quantitative means of testing the effectiveness of an advertising campaign. ${ }^{96}$ This is determined by calculating the profitability of a company after cost. However it is also important to perform qualitative methods to test the effectiveness of the campaign. To do so they recommend using a communication audit as well as brand and customer loyalty. ${ }^{97}$ Measurement benchmarks are found out through monthly, quarterly, and annually performed analysis of a company's monetary output and input. ${ }^{98}$ The research proved that more testing methods were evident within trade publications and not within the predicted peer-reviewed journal entries. However, one is more likely to find an article on testing methods in a peer-reviewed journal than in a trade publication.

\footnotetext{
${ }^{95}$ Julie Woods. Communications ROI. Communication World; Jan/ Feb 2004, Vol. 21, Issue 1, pg14-18.

${ }^{96}$ http://www.investorwords.com/4316/ROI.html. definition of ROI.

${ }^{97}$ Julie Woods. Communications ROI. Communication World; Jan/ Feb 2004, Vol. 21, Issue 1, pg14-18. ${ }^{98}$ Ibid.
} 
H2: The trade publications will predominantly focus on how the organization is using the campaign.

In the second hypothesis stated that trade publications will focus more on how the organization is using a campaign than on how it is testing and evaluating the campaigns. As discussed in the first hypothesis, out of 242 articles on IMC only 34 of them were actually on testing and evaluation methods. This left 208 articles that discussed integrated marketing communications in other ways. These articles discussed how the IMC campaign was being used and why they used it. From the 208 articles on the use of IMC campaigns 190 of them came from trade publications. This could possibly be due to the fact that these publications are just as they are described, “trade publications” which is defined as a publication that falls between the categories of magazine and journal, with articles focusing on information relating to a particular trade or industry. ${ }^{99}$ So these publications would focus predominantly on the use of this type of campaign strategy instead of how to actually test it. An example of this would be with the Hartz Mountain Corporation awarding a 10 million dollar integrated marketing communication campaign to Kirshenbaum Bond Creative Network. ${ }^{100}$ This article primarily discusses how the Hartz Mountain pet-supply company signed with an advertising firm which will use an IMC campaign to strengthen its spot as the leading pet supply brand. ${ }^{101}$

The peer-reviewed journal articles consisted predominately of discussions and studies concerning the topic of IMC. An example of this would be the use of IMC as a cross-promotional tool. The use of IMC can branch out from not just one form of media

\footnotetext{
${ }^{99}$ http:www.lrc.usuhs.mil/jargon/jargon_words.html. definition of trade publications.

${ }^{100}$ Emily Aronson, Lisa Sanders. Hartz Pounces on Kirshenbaum. Advertising Age; 7/15/2002, Vol. 73, issue 28 , pg 8.

${ }^{101}$ Ibid
} 
but to another at the same time. The use of multiple media outlets at the same time can enhance the effectiveness of one of the mediums used to better reach your target audience. ${ }^{102}$ These types of studies are very evident in peer-review journals as opposed o trade publications. The researcher has proved that trade publications focus more on the use of IMC within a campaign. Peer-reviewed journals primarily use the topic of IMC within a study or a discussion.

H3: Trade publications will predominantly focus on the qualitative aspects of an IMC campaign rather than the quantitative.

In hypothesis three it suggested that there would be more qualitative methods for testing an IMC campaign as opposed to quantitative methods. Through the content analysis it has revealed that there are typically more qualitative testing methods discussed in trade publications than in peer-reviewed journals. Of the 18 trade publication articles concerning methods of evaluating the effectiveness of an IMC campaign, 11 of the 18 (61\%) discussed qualitative testing methods. Only three articles discussed only quantitative method and there were also four articles that discussed types of evaluation tactics. The most common way of evaluation was with brand recognition and brand imaging. This is a typical qualitative testing method in which companies wish to use this campaign to create a long term positive brand image within the consumer. ${ }^{103}$ The effects are not seen right away as a ROI quantitative method. However, if the campaign is successful then the effects will be seen later down the road. The primary method for quantitative testing is the return of investment method. There are four steps that the

\footnotetext{
${ }^{102}$ Hyun Seung Jin. Compounding Consumer Interest. Journal of Advertising; Winter 03/04, Vol. 32, issue 4, pg 29-30.

${ }^{103}$ Don E. Schultz. Thinking Big Picture. Marketing News; 11/15/2005, Vol. 39, issue 19, pg 30, 32.
} 
researcher must follow to accurately determine the ROI. ${ }^{104}$ First, specific information of your audience or customers must be identified through accurate household information. Second, the researcher must determine the value of the consumer by estimating the immediate return of the customer to the company. The third step is the ability to track how the consumer is receiving the message. What media are they using and how often are they being exposed to our message. The final step is the consumer's response to the company message. Did they purchase anything or did they make an inquiry about more information on the company or product. ${ }^{105}$ These steps help determine the ROI for IMC campaigns.

H4: Journal publications will predominantly discuss the quantitative aspect of the campaign.

This hypothesis states that peer-reviewed journals discuss quantitative testing methods more than qualitative strategies. Through the analysis it has shown that 15 out of the 16 (94\%) articles from peer-reviewed journals describe qualitative evaluation methods. Brand orientation is described as an approach in which the process of the organization revolve around the creation, development, and protection of brand identity in an ongoing interaction with target customers with the aim of achieving lasting competitive advantages. ${ }^{106}$ This is a way for a company to maintain its identity with the public by constantly keeping contact with the consumer and making changes to the campaign to best keep the consumer's interest and loyalty to the brand.

\footnotetext{
${ }^{104}$ Don E. Schultz. Trying to Determine ROI for IMC. Marketing News; 1/3/94, Vol. 28, issue1, pg 18. ${ }^{105}$ Ibid.

${ }^{106}$ Mike Reid, Sandra Luxton, Felix Mavondo. The Relationship Between Integrated Marketing Communication, Marketing Orientation, and Brand Orientation. Journal of Advertising; Winter 2005, Vol. 34, issue 4, pg 16.
} 
As compared to hypothesis three there were more qualitative testing methods in peer-reviewed journals than in trade publications. Both types of publications had more qualitative methods than quantitative. A total of 26 out of the 34 evaluation method articles discussed qualitative ways to test. The remaining 8 articles used the method of ROI to test the quantitative aspect of the campaign. The researcher found that this hypothesis was proven false and that peer-reviewed journals discussed qualitative methods for testing the effectiveness of an IMC campaign.

H5: There will be more articles on the use and practice of IMC than there will be on the actual testing of an IMC campaign in both types of publications.

The fifth hypothesis stated that there are more articles in both peer-reviewed journals and trade publications discussed the use and practice of IMC than on the actual testing of a campaign. From the content analysis it has shown that out of the 242 articles containing the subject matter of integrated marketing communication 208 of them were on the use and practice of IMC tactics. A major reason for this is that an actual IMC standard evaluation method has not been created to determine its effectiveness. Don Schultz and Philip Kitchen state that, “we can’t measure IMC now and it may be some time before we can.”107 Until an actual method is used companies will continue to use testing methods associated with public relations and advertising fields. This hypothesis was shown to be correct in that there were more articles concerning the use and practice of IMC than on the testing of it.

\footnotetext{
${ }^{107}$ Don E. Schultz, Philip J. Kitchen. A Response to "Theoretical Concept or Management Fashion?". Journal of Advertising Research; Sept/Oct 2000, Vol. 40, issue 5, pg 19.
} 
H6: Integrated Marketing Communications will have been discussed more in the 2000's publications than in the 1990's publications.

Hypothesis six states that there will be more articles on IMC within the publications from the 2000's than in the 1990's. From the study, a total of 242 articles were found which contained the subject of IMC. Of those articles 126 (52\%) were from the 2000's and 116 (48\%) were from the 1990’s. A factor in why this might occur is that IMC was created in 1991. When it was created, many advertising and public relation professionals were reluctant to use its tactics since other concepts like IMC have failed in the past trying to combine both advertising and communication strategies. ${ }^{108}$ As a result the concept did not start being used until the decline of the advertising industry. The advertising industry had to combine tactics to stay competitive and to maintain their profitability. $^{109}$

\section{CONCLUSION}

Through all of the research concerning integrated marketing communications some key information is striking. Though it is a relatively new field it is so widely used that more and more companies are adopting its attributes. Even with all of its uses, publications still do not choose to write or thoroughly discuss the attributes and testing methods associated with IMC. This is possibly due to the fact that since IMC is still widely viewed as a concept or theory many professional publications will not report on its use or practices. Another possible reason is the fact that these printings are specifically associated with a particular field and will only discuss issues associated with that field.

\footnotetext{
${ }^{108}$ Heath, Handbook of Public Relations, 209

${ }^{109}$ Hutton, Marketing Communications, 6.
} 
The researcher found that even though there were very few articles containing IMC, that peer-reviewed journals predominantly discussed qualitative methods of evaluating an IMC campaign. These testing methods were predominantly based on the public's views on either the product or the company associated with the product.

A very interesting finding as a result of this study was the absence of an effective quantitative testing method for IMC. Though some techniques were listed, like ROI and Benchmarks, they are still seen as forms of testing for advertising and not an actual test for IMC. The reason that they are not deemed to be efficient is there other variables to take into account to determine the effectiveness. A major variable is the fact that these quantitative methods are typically for a set time frame and not used specifically during or after the campaign. Outside factors can influence the rise or fall of a company's profitability. IMC still does not have a set quantitative process for examining the use of campaigns using this technique. Until there is a standardized way to test IMC it will always remain a theory.

This study was limited due to the fact that the sample was bounded by only using 10 publications from the fields of advertising, public relations, and marketing. It shortened the amount of articles that could contain IMC topics. Another limitation was the use of only two marketing publications, one peer-reviewed journal and one trade publication. There should have been the same amount of marketing publications as the rest of the sample to expand on the study. By doing so it will have evened out the amount of publications used and gathered a higher number of results from the content analysis 
To expand on this study the researcher should first include a wider variety of publications including specifically design printings for integrated marketing communications. If the researcher is trying to find testing methods specifically for IMC then they should first look in that field's publications. Instead of trying to find testing techniques about a theoretical field in other printings the researcher should look directly at IMC printings. Another way to expand the study would be to enlarge the sample size date from the 10 years to 14 years. This would cover IMC from its conception in 1991 to current times. By increasing the time frame it should enlarge the amount of information on evaluation methods due to the fact that there were probably more articles written about IMC during its conception instead of how it is looked at now.

Through this study the researcher has noticed that IMC is a growing field. Though it is a new program that combines two major aspects used by many corporations it still has several weaknesses which limits its capabilities to a theory. An example of this is that an actual quantitative testing method does not yet exist specifically designed for an IMC campaign. Until IMC can develop accurate and timely means to test its efficiency then IMC will remain just a concept and not an actual practice. 


\section{BIBLIOGRAPHY}

ARONSON, Emily., SANDERS, Lisa., HARTZ POUNCES ON KIRSHENBAUM. Advertising Age; Vol. 73, issue 28, pg 8.

ATKINSON, Claire., IT'S THE MARKETERS' 'APPRENTICE'. Advertising Age; Vol. 75 , issue 35 , pg 1-2.

BALASUBRAMANIAN, Siva K., BEYOND ADVERTISING AND PUBLICITY: HYBRID MESSAGES AND PUBLIC POLICY ISSUES. Communication World; Vol. 23, issue 4, pg 29-47.

BELTRAMINI, Richard F., EXPLORING THE EFFECTIVENESS OF BUSINESS GIFTS: REPLICATION AND EXTENSION. Journal of Advertising; Vol. 29, issue 2, pg 75-79.

BURNS, Darren J., CAMPAIGN TURNS TO ‘GHOSTS’ TO RALLY PAPER TOWEL SALES IN TAIWAN. Communication World; Vol. 21, issue 3, pg 54-55.

CAYWOOD, Clarke. THE HANDBOOK OF STRATEGIC PUBLIC RELATIONS \& INTEGRATED COMMUNICATIONS. McGraw Hill, Boston, MA, 1997.

CLOW, Kenneth. INTEGRATED ADVERTISING, PROMOTION \& MARKETING COMMUNICATONS. Prentice Hall, New Jersey, 2002.

CORNWELL, Bettina., ROY, Donald., STEINARD II, Edward A., EXPLORING MANAGERS' PERCEPTIONS OF THE IMPACT OF SPONSORSHIP ON BRAND EQUITY. Journal of Advertising; Vol. 30, issue 2, pg 41-52.

CRAIN, Rance., TURBULENCE HITS AD SCHOOL: FUNDS CUT, ACADEMIC FEUDING. Advertising Age; Vol. 74, issue 46, pg 18.

CRAIN, Rance., ACADEMIC WISHFUL THINKING MAY BE END OF IMC PROGRAM. Advertising Age; Vol. 73, issue 40, pg 20.

DEBRECENY, Peter., COCHRANE, Lisa., TWO DISCIPLINES ON SAME ROAD. Advertising Age; Vol. 75, issue 45, pg 28.

DILLARD, James P., PECK, Eugenia. AFFECT AND PERSUASION: EMOTIONAL RESPONSES TO PUBLIC SERVICE ANNOUNCEMENTS. Communication Research; Vol. 27, No. 4, August 2000, pg 461-495.

DIPASQUALE, Cara B., THE IDEAL CANDIDATE. Advertising Age; Vol. 73, issue 8, pg 22. 
DIPASQUALE, Cara B., THINKING OUTSIDE THE AGENCY BOX. Advertising Age; Vol. 73, issue 8, pg 22.

DUNCAN, Thomas R.; EVERETT, Stephen .E. CLIENT PERCEPTIONS OF INTEGRATED MARKETING COMMUNICATIONS. Journal of Advertising Research, New York, May/June 1993, pg 30-40.

ELKIN, Tobi., MAUREEN MCGUIRE. Advertising Age; Vol. 72, issue 41, pg 17.

ELKIN, Tobi., IBM TAKES DIRECT AIM AT RIVAL SUN IN FRESH ADS. Advertising Age; Vol. 71, issue 30, pg 48-49.

FERNANDO, Angelo., BIG BLOGGER IS WATCHING YOU! REPUTATION MANAGEMENT IN AN OPIONATED, HYPERLINKED WORLD. Communication World; Vol. 21, issue 4, pg 10-11.

FERNANDO, Angelo., CREATING BUZZ: NEW MEDIA TACTICS HAVE CHANGED THE PR AND ADVERTISING GAME. Communication World; Vol. 21, issue 6, pg 10-11.

FERNANDO, Angelo., 'I WASN'T HIRED TO DO THAT'-TECHNICALLY, NO; BUT TECHNICALLY, YES. Communication World; Vol. 21, issue 5, pg 10-11.

FILL, Chris. MARKETING COMMUNICATIONS: FRAMEWORKS, THEORIES, AND APPLICATIONS. Prentice Hall, London, 1995.

GORDON, Janine. WHEN PR MAKES MORE SENSE THAN ADS. Brandweek; Vol. 44, issue 16, 2003.

Ed. HEATH, Robert. HANDBOOK OF PUBLIC RELATIONS. Sage Publishing, Thousand Oaks, CA, 2001.

HERSEY, Lewis. A PERFORMANCE-CENTERED APPROACH TO MARKETING EDUCATION. Journal for Advancement for Marketing Education; Vol. 1, 2001.

HOFFMAN, Donna L., NOVAK, Thomas P. MARKETING IN HYPERMEDIA COMPUTER-MEDIATED ENVIRONMENTS. Journal of Marketing. Vol. 60, pg 50-69.

HOWARD, Carole M., "BUILDING CATHEDRALS"-REFLECTIONS ON THREE DECADES IN CORPORATE PR AND A PEEK AT THE FUTURE. Public Relations Quarterly; Vol. 40, issue 2, pg 5-12.

HUTTON, James G. MARKETING COMMUNICATIONS: INTEGRATED THEORY, STRATEGY \& TACTICS. Pentagram Publishing, New Jersey, 2002. 
HYUN, Seung Jin., COMPOUNDING CONSUMER INTEREST. Journal of Advertising; Vol. 32, issue 4, pg 29-42.

GIBSON, Dirk C., THE WHITECHAPEL CRIMES AS PUBLIC RELATIONS. Public Relations Quarterly; Vol. 47, issue 4, pg 26-33.

GONRING, Matthew P., PUTTING INTEGRATED MARKETING COMMUNICATIONS TO WORK TODAY. Public Relations Quarterly; Vol. 39, issue 3, pg 45-48.

GRUNIG, James \& HUNT, Todd. MANAGING PUBLIC RELATIONS. Holt, Rinehart, and Winston, New York, 1984.

JONES, David., 'HERE'S TO YOU, CANADA' MAKES MOLSON CANADIAN THE TOAST OF THE TOWN. Communication World; Vol. 20, issue 3, pg 38-39.

KITCHEN, Philip J., EAGLE, Lynne. CONCLUSIONS AND CAVEATS. IMC Communique; Winter 2004.

KOTLER, Philip. MARKETING MANAGEMENT: ANALYSIS, PLANNING AND CONTROL. Prentice Hall, 1984.

MADDEN, Charles S., EASLEY, Richard W., HOW JOURNAL EDITORS VIEW REPLICATION RESEARCH. Journal of Advertising; Vol. 24, issue 4, pg 77-88.

MADRIGAL, Robert. THE INFLUENCE OF SOCIAL ALLIANCES WITH SPORTS TEAMS ON INTENTIONS TO PURCHASE CORPORATE SPONSORS' PRODUCTS. Journal of Advertising; Vol. 29, issue 4, pg 13-25.

MARIOTTI, John. UNDERSTANDING INFLUENCE AND PERSUASION, Industry Week, Vol. 248, 1999.

MARKEN, G. A., VALUE-ADDED PUBLIC RELATIONS: THE SECRET WEAPON OF INTEGRATED MARKETING. Public Relations Quarterly; Vol. 49, issue 2, pg 16.

MCCARTHY, E. Jerome. BASIC MARKETING. Richard D. Irwin, Inc., Illinois, 1981.

MCGOON, Cliff., CUTTING-EDGE COMPANIES USE INTEGRATED MARKETING COMMUNICATION. Communication World; Vol. 16, issue 1, pg 15-19.

MORIARTY, Sandra E., PR AND IMC: THE BENEFITS OF INTEGRATION. Public Relations Quarterly; Vol. 39, issue 3, pg 38-44.

NEMEC, Richard., PR OR ADVERTISING-WHO'S ON TOP? Communication World; Vol. 16, issue 3, pg 25-28. 
PERCY, Larry. STRATEGIES FOR IMPLEMENTING INTEGRATED MARKETING COMMUNICATIONS. NTC Business Books, Linconlwood, IL, 1997.

POWERS, Thomas L. SHOULD YOU INCREASE SALES PROMOTION OR ADD SALESPEOPLE? Communication World; Vol. 18, issue 4, pg 259-263.

REICH, Ken. SOME THINGS STILL WORK DON'T THEY? Communication World; Vol. 18, issue 3, pg 27-29.

REID, Mike. LUXTON, Sandra., MAVONDO, Felix. THE RELATIONSHIP BETWEEN INTEGRATED MARKETING COMMUNICATION, MARKETING ORIENTATION, AND BRAND ORIENTATION. Journal of Advertising; Winter 2005, Vol. 34, issue 4, pg 16.

RUST, Roland T., OLIVER, Richard W., THE DEATH OF ADVERTISING. Journal of Advertising; Vol. 23, issue 4, pg 71-78.

SCHULTZ, Don E., KITCHEN, Philip J., A RESPONSE TO "THEORETICAL CONCEPT OR MANAGEMENT FASHION?". Journal of Advertising Research; Sept/Oct 2000, Vol. 40, issue 5, pg 19.

SCHULTZ, Don E. THINKING BIG PICTURE. Marketing News; 11/15/2005, Vol. 39, issue 19, pg 30, 32.

SCHULTZ, Don E. TRYING TO DETERMINE ROI FOR IMC. Marketing News; 1/3/94, Vol. 28, issue1, pg 18.

SIMONS, Herbert W. PERSUASION IN SOCIETY. Sage Publications, Inc., California, 2001.

STEVENS, Art., PUBLIC RELATIONS IN THE YEAR 2000. Public Relations Quarterly; Vol. 41, issue 2, pg 19-22.

Ed. THORSON, Esther. INTEGRATED COMMUNICATIONS. Lawrence Erlbaum Associates Publishers, New Jersey, 1996.

WIGHTMAN, Ben., INTEGRATED COMMUNICATIONS: ORGANIZATION AND EDUCATION. Public Relations Quarterly; Vol. 44, issue 2, pg 18-22.

WIGHTMAN, Ben., THE CUSTOMER CENTURY: LESSONS FROM WORLD-CLASS COMPANIES IN INTEGRATED MARKETING AND COMMUNICATIONS. Public Relations Quarterly; Vol. 45, issue 3, pg 8.

WOODS, Julie. COMMUNICATIONS ROI. Communication World; Vol. 21, issue 1, pg 14-18. 
WEBSITE: www.medill.nwu.edu/alumni/ medillian/summer02/imc.pdf

WEBSITE: changingminds.org/explanations/theories/persuasion.htm

WEBSITE: http:www.lrc.usuhs.mil/jargon/jargon_words.html.

WEBSITE: http://www.investorwords.com/4316/ROI.html. 